\title{
Thermodynamic characterization of three centered hydrogen bond using $o$-aromatic amides, oxalamates and bis-oxalamides as model compounds
}

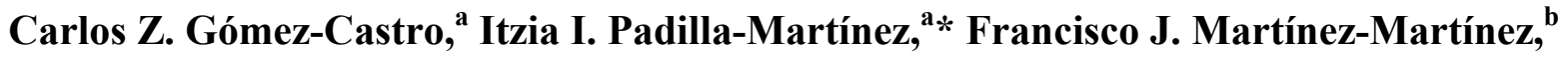 \\ and Efrén V. García-Báez ${ }^{a}$ \\ ${ }^{a}$ Departamento de Química, Unidad Profesional Interdisciplinaria de Biotecnología del Instituto \\ Politécnico Nacional. Av. Acueducto s/n Barrio la Laguna, \\ Ticomán. México D. F. 07340, Mexico \\ ${ }^{b}$ Facultad de Ciencias Químicas, Universidad de Colima, km 9 Carretera Coquimatlán-Colima, \\ Colima 28400, Mexico \\ E-mail: ipadillamar@ipn.mx
}

\begin{abstract}
This manuscript is dedicated in honor of Professor Rosalinda Contreras Theurel on the occasion of her $60^{\text {th }}$ birthday
\end{abstract}

\begin{abstract}
The study of the thermodynamic properties and cooperativity involved in three centered hydrogen (THB) bond formation using aromatic ortho-A substituted amides, oxalamates and bisoxalamides $\left(\mathrm{A}=\mathrm{H}\right.$, OMe, $\left.\mathrm{F}, \mathrm{CH}_{2} \mathrm{OH}, \mathrm{NO}_{2}, \mathrm{COCH}_{3}\right)$ as model molecules is reported. $\Delta H^{\circ}$ and $\Delta S^{\circ}$ associated with disruption of intramolecular hydrogen bonding by solvent were estimated using temperature dependence data of the N-H chemical shift. The results suggest that the influence of the A group is more important when electron-withdrawing, increasing both the enthalpy and entropy with an important contribution from conformational changes. The data allowed the estimation of the $\mathrm{Ph}=\mathrm{NH}^{+}$rotational barrier of $14.0 \mathrm{~kJ} \mathrm{~mol}^{-1}$ in the amide and 16.7$18.0 \mathrm{~kJ} \mathrm{~mol}^{-1}$ in oxalyl moiety. Correlations between $\Delta H^{\circ}$ and $\Delta S^{\circ}$ with $\mathrm{NH}$ temperature gradients predicted an enthalpy change of 18.7(1.0) and 24.4(1.7) $\mathrm{kJ} \mathrm{mol}^{-1}$ for the energy required to break a full THB bond $(\mathrm{A} \cdots \mathrm{H} \cdots \mathrm{O}=\mathrm{C})$ and entropy differences between the non hydrogen bonded and hydrogen bonded state of 42.0(4.7) and 61.9(11) $\mathrm{J} \mathrm{mol}^{-1} \mathrm{~K}^{-1}$ in oxalamate and bis-oxalamide series, respectively, in agreement with the participation of cooperative effects.
\end{abstract}

Keywords: Three centered hydrogen bond, temperature gradients, oxalamides, oxalamates 


\section{Introduction}

The pioneering study on three centered hydrogen bonding using aromatic amides, oxalamates and bis-oxalamides was developed by Martínez-Martínez, ${ }^{1}$ in his $\mathrm{PhD}$ dissertation under the supervision of Professor Rosalinda Contreras. This contribution, in her honor, is intended to provide further insights into the understanding of the energetic requirements of THB formation in such systems. The three centered hydrogen bond (THB) is one of the two modes of bifurcated hydrogen bonding which is known to occur. ${ }^{2}$ It can be characterized as that configuration where a hydrogen atom covalently bonded to an electronegative atom is hydrogen bonded to another two lying in or close to the plane defined by them. ${ }^{3}$ This kind of interaction frequently occurs in crystal structures of organic molecules, ${ }^{4}$ and biomolecules such as aminoacids, ${ }^{5}$ proteins, ${ }^{6}$ and DNA. ${ }^{7,8}$ Intramolecular THB has been claimed to rigidify oligomer structures ${ }^{9}$ and to control the helical secondary structure of oligoanthranilamides. ${ }^{10}$ In spite of its wide occurrence, much less is known about the energy involved in this interaction. In fact there is a controversy about the energetic superiority of THB over regular or two centered HB. There are some studies that provide experimental evidence in favor, ${ }^{11-13}$ however some experimental ${ }^{14,15}$ and theoretical studies, ${ }^{3}$ using flexible molecules as a model, provide contrary evidence.

For a long time, the temperature dependence of amide N-H proton chemical shift has been recognized to be a useful tool to evaluate the thermodynamic parameters of intramolecular hydrogen bonding in flexible amides, ${ }^{16}$ specially in non-polar solvents. The method is based on van't Hoff analysis, which requires equilibrium constant values at several temperatures to obtain $\Delta H^{\circ}$ and $\Delta S^{\circ}$ values of the process. The equilibrium constant between non bonded and fully hydrogen bonded state is calculated with the chemical shifts values associated with the fully hydrogen bonded state, non hydrogen bonded state and the observed one. The inconvenience of this methodology, applied in several systems, is that usually the chemical shift of a model molecule is used as the chemical shift for the non-bonded state. On the other hand, studies in polar solvents are limited to peptides since a solvent possessing a high hydrogen bonding capability, like DMSO, can exert a dominant influence on amide hydrogen bonding behavior, acting as a proton quencher. In this solvent, temperature gradient values of amide $\mathrm{N}-\mathrm{H}$ chemical shift $(\Delta \delta / \Delta \mathrm{T})$ below $2 \mathrm{ppb}$ are considered as indicative of solvent shielded or non-exposed systems. ${ }^{17}$ Alternatively, for small systems $\Delta \delta / \Delta T$ values, ${ }^{18}$ as well as solvent induced gradients of the $\mathrm{NH}$ chemical shift and N-H IR stretching frequencies ${ }^{12}$ have been related to the strength of the three centered hydrogen bonding interaction, however, the energy involved has not been estimated.

Our previous studies on oxalamide derivatives have demonstrated the existence of THB both in DMSO solution ${ }^{1}$ and in solid state ${ }^{18}$ and have also established the role of tautomeric equilibria on the stability of these systems. ${ }^{19}$ Furthermore, THB have been used in the design of molecular clefts. ${ }^{20}$ Aromatic bis-oxalamides possess structural features that make them good models for the experimental study of the energy associated with THB, since donor and both acceptor groups occur in the same molecule and are rigidly held in the proper arrangement. Herein, the study of 
the thermodynamic properties and the cooperativity involved in THB formation using aromatic ortho-A substituted amides (a series) as model molecules for regular HB, oxalamates (b series) as model molecules for THB and bis-oxalamides (c series) as models for both THB and cooperativity, is reported ( $\mathrm{A}$ is the hydrogen bonding acceptor group).

Competition between intramolecular hydrogen bonding interaction and deuterated DMSO hydrogen bonding is studied measuring the changes in the equilibrium population induced by temperature. The methodology developed by Llor et al., ${ }^{21}$ for a process in fast chemical exchange, is used to evaluate the chemical shifts for the hydrogen bonded state $\left(\delta_{\mathrm{HB}}\right.$ at low temperature) and solvent (DMSO) hydrogen bonded species ( $\delta_{\mathrm{SB}}$ at high temperature), assuming that the observed chemical shift $\left(\delta_{\text {obs }}\right)$ is a weighted average of these contributing forms. The method, based on the pioneering work of Gutowsky and Saika, ${ }^{22}$ also provides the value of the equilibrium constant $K_{R}$ at the reference temperature $(303 \mathrm{~K})$ and an estimation of the enthalpy of the process. The low and high temperature chemical shifts were used to evaluate the equilibrium constant for the process at several temperatures and after using the van't Hoff treatment, $\Delta H^{\circ}$ and $\Delta S^{\circ}$ were estimated.<smiles></smiles>

a<smiles>CCOC(=O)C12COCc3cccc(c31)C2</smiles>

b

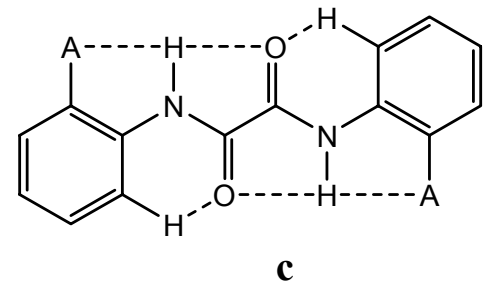

c

$\mathrm{A}=1 \mathrm{H}, 2 \mathrm{OCH}_{3}, 3 \mathrm{~F}, 4 \mathrm{CH}_{2} \mathrm{OH}, 5 \mathrm{NO}_{2}, 6 \mathrm{COCH}_{3}$<smiles>COCN(Cc1ccccc1OC)C(C)=O</smiles>

$7 \mathbf{a}$<smiles>CCOC(=O)C(=O)N1Cc2ccccc2OC1OC</smiles>

$7 \mathbf{b}$<smiles>COc1ccccc1CN1C(=O)C2OC3COc4ccccc4CN1C(O3)C2=O</smiles>

$7 \mathrm{c}$

\section{Results and Discussion}

A series of aromatic amides, oxalamates and bis-oxalamides (a, b and c series, respectively) varying the ortho-substituent from electron-donating $(2, \mathrm{~A}=\mathrm{OMe})$ to electron-withdrawing capabilities $\left(\mathbf{3}, \mathrm{A}=\mathrm{F} ; \mathbf{5}, \mathrm{A}=\mathrm{NO}_{2} ; \mathbf{6} \mathrm{A}=\mathrm{COCH}_{3}\right)$ were used as model compounds, amides as models for regular HB, oxalamates for THB and bis-oxalamides to test cooperativity in THB. Furthermore, five (compounds 2 and 3), versus six membered (compounds 4-7) hydrogen 
bonded rings can be evaluated. It should be mentioned that derivatives from $o$-hydroxyaniline were not included to avoid the interference of exchange phenomena between $\mathrm{N}-\mathrm{H}$ and $\mathrm{O}-\mathrm{H}$ hydrogen atoms in solution.

\section{Reliability of experimental data}

The graphs of temperature vs N-H chemical shifts for a-c series are shown in Figures 1a-c. In every case the NH chemical shifts decrease as the temperature increases. The method adjusts the data to a sigmoidal curve by Non Linear Fitting Procedures (NLFP) (Figure 1d), from which $\delta_{H B}$ and $\delta_{S B}$ values are predicted. The results of the non-linear fitting procedure are listed in Table 1 and van't Hoff results are in Table 2. The method estimates $\delta_{H B}$ values with the lowest error whereas $K_{R}$ is estimated with the highest error. $\Delta H^{\circ}$ and $\delta_{S B}$ values are moderately well estimated but the van't Hoff estimations for $\Delta H^{\circ}$ are more accurate, thus these last values, are used for discussion purposes.
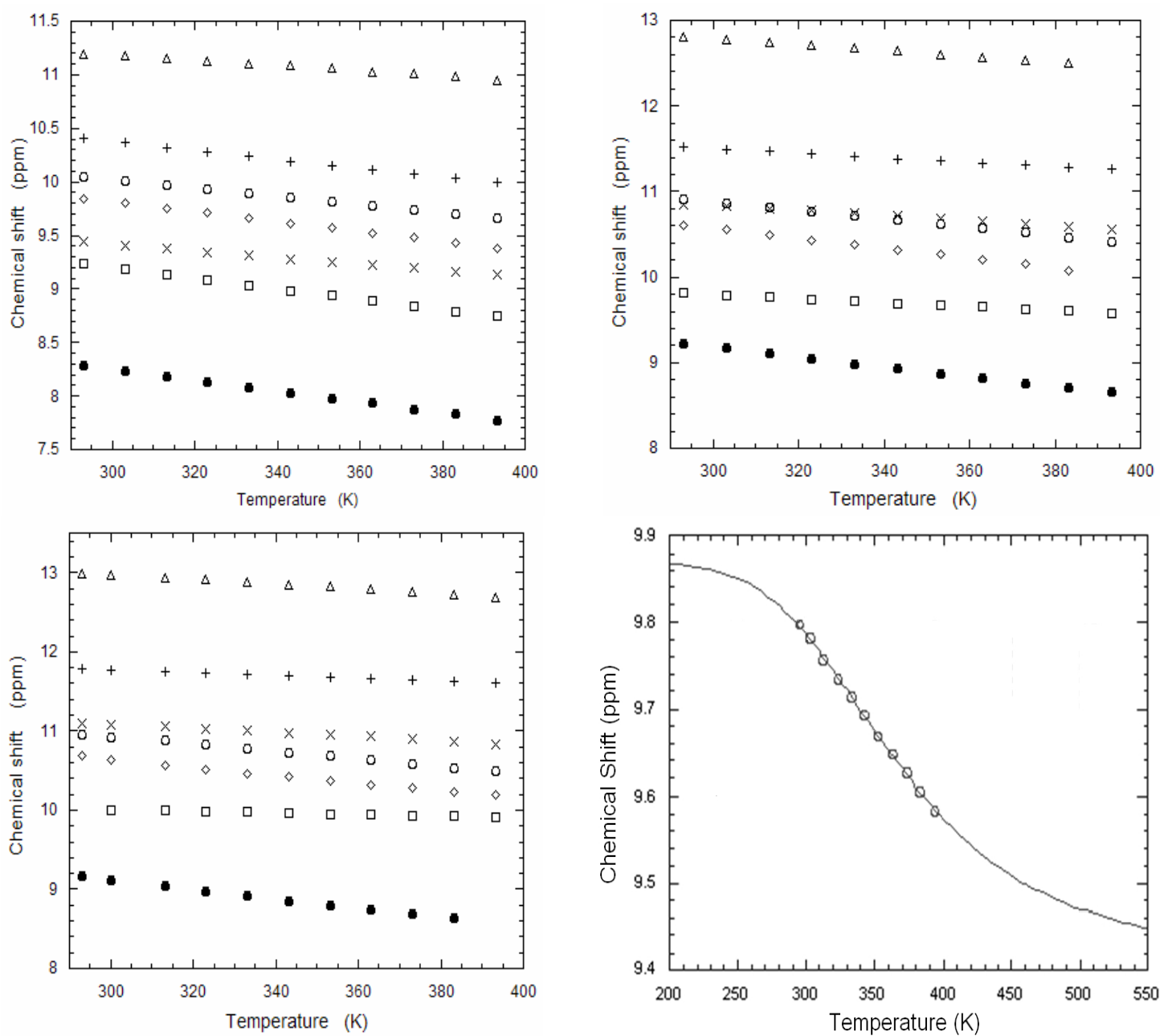

Figure 1. Temperature vs chemical shift plots for the N-H proton in $\mathbf{a}, \mathbf{b}$ and $\mathbf{c}$ series, respectively. Compounds $1(\circ), 2(\square), 3(\diamond), 4(\times), 5(+), 6(\Delta)$ and $7(\bullet)$ d) Sigmoidal curve adjusted by NLFP for compound $\mathbf{2 b}$. 
As mentioned before, the method predicts a low temperature chemical shift $\delta_{H B}$, associated with the full hydrogen bonded state, and a high temperature chemical shift $\delta_{S B}$, associated with the solvent bonding state. Independently from the $o$-substituting group, the predicted $\delta_{H B}$ values for oxalamate $\mathbf{b}$ and bis-oxalamide $\mathbf{c}$ series are larger than the values for amide a series and both converge to the same value. This prediction is in accordance with the expected hydrogen bonded state for the amide and three centered hydrogen bonded state for the oxalamate $\mathbf{b}$ and bisoxalamide c series. In contrast, the predicted value for $\delta_{S B}$ is different between the series. This result is expected due to different degrees of solvent association (b and $\mathbf{c}$ series) or even solvent exchange (a series). Solvation of $\mathbf{b}$ and $\mathbf{c}$ series is in agreement with the model proposed for amines and phenol by Lewis bases. ${ }^{23}$ Thus, the predicted $\Delta H^{\circ}$ and $\Delta S^{\circ}$ values may be overestimated in the order amides $>>$ oxalamates $>$ bis-oxalamides. In every case both enthalpy and entropy changes are positive, in agreement with the energy required to disrupt hydrogen bonding and to reach a more disordered final state.

\section{Structure effects on hydrogen bonding energetics}

The electronic nature of the hydrogen bonding acceptor group exerts a strong influence on the amide NH signal, which is shifted to low frequencies by electron-donating groups $(\mathrm{A}=\mathrm{D})$ and to high frequencies by electro withdrawing groups $(\mathrm{A}=\mathrm{W})$ [compare for example $\delta \mathrm{NH}_{H B}(\mathbf{2} \mathbf{a}, \mathrm{A}=$ $\mathrm{OMe})=9.7$ and $\left.\delta \mathrm{NH}_{H B}\left(\mathbf{5 a}, \mathrm{A}=\mathrm{NO}_{2}\right)=11.32\right]$. The shielding and deshielding effects of substituents are in agreement with the participation of different resonance structures in solution. In the case of electro-D substituents, the amide nitrogen lone pair of electrons is delocalized to the carbonyl moiety (B form) and in the case of electro-W groups it is preferentially delocalized to the phenyl ring ( $\mathbf{C}$ form). Both ionic forms are stabilized by polar solvents such DMSO whereas the A form will be the predominant canonical structure in non polar solvents. If either of resonance structures $\mathbf{B}$ or $\mathbf{C}$ takes part in hydrogen bonding, the acidity of the $\mathrm{NH}$ is thus increased, but in the case of $\mathbf{C}$ a contribution from rotational effects in $\mathrm{Ph}-\mathrm{NH}$ bond can also be expected.

The $\beta$-carbonyl group from the oxalyl moiety exerts an important local deshielding effect on the N-H signal, shifting it to higher frequencies by approximately $\Delta \delta_{H B}=0.8 \mathrm{ppm}$ (compare the values of $1 \mathbf{a}$ and $\mathbf{1 b}$ ). Changes in conformation induced by THB formation are responsible for $\Delta \delta_{H B}$ higher than $0.8 \mathrm{ppm}$ and for the small change observed for compounds $\mathbf{2 b}$ and $\mathbf{2 c}(\mathrm{A}=$ $\mathrm{OMe}$ ) in relation to compound $\mathbf{2 a}$.

After a brief comparison of $\Delta H^{\circ}$ between compounds $\mathbf{1 a}$ and $\mathbf{1 b}$-c, it is inferred that the oxalyl group has a small but noticeable influence increasing $\Delta H^{\circ}$ of the process by $2.1(0.2) \mathrm{kJ}$ $\mathrm{mol}^{-1}$ mean value. It has been proposed that the intramolecular interaction between $\mathrm{N}-\mathrm{H}$ and its $\beta-\mathrm{CO}$ group in oxalamides, should be considered as a favorable interaction of antiparallel local

dipoles, ${ }^{24}$ then the value of $2.1(0.2) \mathrm{kJ} \mathrm{mol}^{-1}$ is proposed as the value for this interaction in aromatic oxalamate and bis-oxalamide compounds. This result is consistent along the a-c series, independently from the nature of the A group, except in the case of compounds 7a-c, whose NHCO group is non aromatic. 

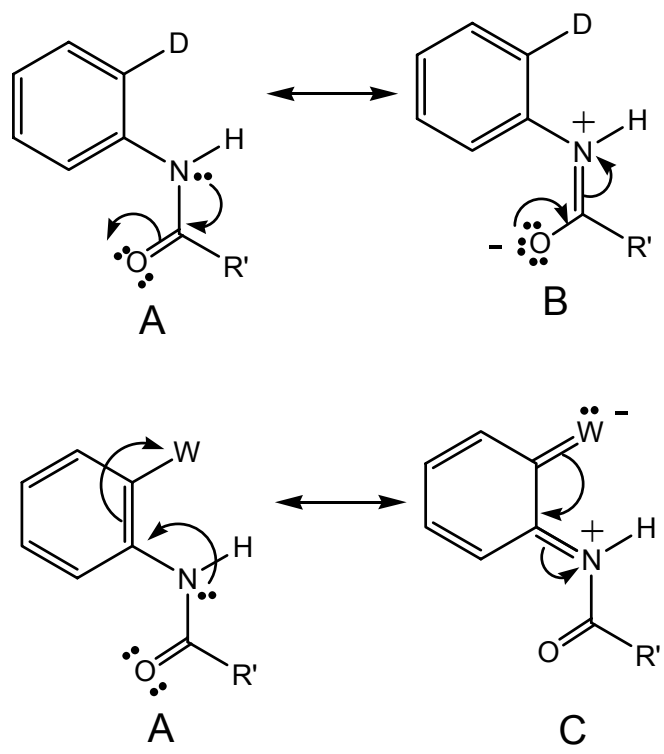

Table 1. Temperature gradients of the N-H chemical shift $(\Delta \delta \mathrm{NH} / \Delta T)$, estimated parameters from NLFP and their standard errors for compounds 1a-c to 7a-c

\begin{tabular}{|c|c|c|c|c|c|}
\hline Comp. & $-(\Delta \delta \mathrm{NH} / \Delta T) / \mathrm{ppb} \mathrm{K}^{-1}$ & $K_{303}$ & $\delta_{H B}$ & $\delta_{S B}$ & $\Delta H^{o} / \mathrm{kJ} \mathrm{mol}^{-1}$ \\
\hline 1a & $3.97 \pm 0.01$ & $0.17 \pm 0.02$ & $10.38 \pm 0.07$ & $7.9 \pm 0.2$ & $9.6 \pm 0.2$ \\
\hline $\mathbf{1 b}$ & $4.90 \pm 0.04$ & $0.15 \pm 0.03$ & $11.20 \pm 0.15$ & $8.6 \pm 0.5$ & $11.8 \pm 0.5$ \\
\hline 1c & $4.87 \pm 0.01$ & $0.194 \pm 0.006$ & $11.29 \pm 0.03$ & $9.02 \pm 0.06$ & $11.5 \pm 0.1$ \\
\hline $2 a$ & $4.97 \pm 0.04$ & $0.27 \pm 0.02$ & $9.7 \pm 0.1$ & $7.2 \pm 0.2$ & $9.5 \pm 0.2$ \\
\hline $2 \mathbf{b}$ & $2.32 \pm 0.01$ & $0.18 \pm 0.05$ & $10.0 \pm 0.2$ & $8.6 \pm 0.3$ & $9.6 \pm 0.6$ \\
\hline 2c & $0.99 \pm 0.01$ & $0.11 \pm 0.07$ & $10.05 \pm 0.02$ & $9.5 \pm 0.1$ & $12.9 \pm 0.5$ \\
\hline $3 \mathbf{a}$ & $4.72 \pm 0.02$ & $0.15 \pm 0.02$ & $10.2 \pm 0.1$ & $7.40 \pm 0.03$ & $10.8 \pm 0.03$ \\
\hline $3 b$ & $5.7 \pm 0.03$ & $0.27 \pm 0.02$ & $11.01 \pm 0.1$ & $8.8 \pm 0.1$ & $11.9 \pm 0.3$ \\
\hline $3 c$ & $4.9 \pm 0.1$ & $0.47 \pm 0.03$ & $11.2 \pm 0.1$ & $9.52 \pm 0.04$ & $12.2 \pm 0.2$ \\
\hline $4 a$ & $3.07 \pm 0.03$ & $0.28 \pm 0.02$ & $9.7 \pm 0.1$ & $8.3 \pm 0.1$ & $9.9 \pm 0.3$ \\
\hline $4 b$ & $3.03 \pm 0.05$ & $0.11 \pm 0.01$ & $10.96 \pm 0.02$ & $9.7 \pm 0.1$ & $15.3 \pm 0.3$ \\
\hline $4 c$ & $2.7 \pm 0.05$ & $0.11 \pm 0.03$ & $11.22 \pm 0.06$ & $9.8 \pm 0.3$ & $13.6 \pm 0.7$ \\
\hline $5 \mathbf{a}$ & $4.11 \pm 0.05$ & $0.32 \pm 0.02$ & $10.9 \pm 0.1$ & $8.67 \pm 0.09$ & $8.3 \pm 0.2$ \\
\hline $5 b$ & $2.62 \pm 0.03$ & $0.32 \pm 0.02$ & $11.68 \pm 0.03$ & $10.91 \pm 0.02$ & $14.6 \pm 0.3$ \\
\hline $5 c$ & $1.92 \pm 0.02$ & $0.25 \pm 0.01$ & $11.85 \pm 0.02$ & $11.46 \pm 0.02$ & $21.1 \pm 0.7$ \\
\hline $6 \mathbf{a}$ & $2.4 \pm 0.05$ & $0.06 \pm 0.04$ & $11.32 \pm 0.09$ & $8.7 \pm 1.7$ & $11.6 \pm 0.8$ \\
\hline $6 b$ & $3.41 \pm 0.04$ & $0.11 \pm 0.02$ & $12.97 \pm 0.06$ & $11.54 \pm 0.09$ & $13.6 \pm 0.3$ \\
\hline 6c & $2.99 \pm 0.05$ & $0.15 \pm 0.02$ & $13.13 \pm 0.08$ & $12.01 \pm 0.1$ & $16.4 \pm 0.6$ \\
\hline $7 a$ & $5.08 \pm 0.03$ & $0.16 \pm 0.03$ & $8.6 \pm 0.2$ & $5.9 \pm 0.5$ & $11.3 \pm 0.6$ \\
\hline $7 b$ & $6.8 \pm 0.2$ & $0.5 \pm 0.1$ & $10.5 \pm 2.7$ & $7.3 \pm 0.5$ & $8.5 \pm 0.1$ \\
\hline $7 c$ & $6.10 \pm 0.08$ & $0.33 \pm 0.01$ & $9.9 \pm 0.3$ & $7.05 \pm 0.06$ & $9.1 \pm 0.1$ \\
\hline
\end{tabular}


The nature of the hydrogen bonding acceptor group A on the energetics of hydrogen bonding disruption can be appreciated by the quotient: $\Delta Y_{A}=\Delta Y_{n a-c}^{o} \Delta Y_{1 a-c}^{o}$, where $\Delta Y_{n a-c}^{o}$ is the estimated enthalpy $(Y=H)$ or entropy $(Y=S)$ for each one of 1a-c to $7 \mathbf{a}-\mathbf{c}$ and $\Delta Y^{o}{ }_{1 a-c}$ is the enthalpy or entropy for each reference compounds 1a-c. Thus $\Delta H_{O M e}$ values for $\mathbf{2 c}$ are $\Delta H^{\circ}(\mathbf{2 c}) / \Delta H^{\circ}(\mathbf{1 c})=12.92 / 11.49=1.1$ (Table 2). $\Delta H_{A}$ values increase in 5a-c series $\left(\mathrm{A}=\mathrm{NO}_{2}\right.$, six membered ring): $\mathbf{5} \mathbf{a}<\mathbf{5 b}<\mathbf{5} \mathbf{c}$; but decreases in $\mathbf{7 a - c}(\mathrm{A}=\mathrm{OMe}$, non aromatic, six membered ring) series: 7c $<\mathbf{7 b}<\mathbf{7 a}$. In the remaining compounds it remains almost constant as would be expected when there is no influence of the group A. In contrast, $\Delta S_{A}$ tends to increase in 3a-c (A $=\mathrm{F}$, five membered ring), 5a-c $\left(\mathrm{A}=\mathrm{NO}_{2}\right.$, six membered ring) and 6a-c $\left(\mathrm{A}=\mathrm{COCH}_{3}\right.$, six membered ring) and to decrease in compounds 7a-c. These results suggest that the influence of the A group is more important when there is an electron-withdrawing group involved in hydrogen bonding, in the particular case of $\mathrm{A}=\mathrm{NO}_{2}$, both the enthalpy and entropy are increased. This result contrast with the expected one, since electron-withdrawing groups increase the acid character of the $\mathrm{NH}$ and therefore the energy required to break intramolecular $\mathrm{HB}$ should be reduced. The aromatic nature of the amide seems to be an important factor for the strength of THB. In the case of non aromatic amide series 7a-c, the enthalpy diminishes in relation to the unsubstituted compound 1a-c but the entropy is increased according with the flexibility introduced by methylene group and the lack of amide conjugation.

To maintain the influence of the A group constant and appreciate the energetics related with three centered hydrogen bonding (THB) and cooperativity effects, the quotient $\Delta Y_{H B}=\Delta Y_{n a-c}^{o}$ $/ \Delta Y_{n a}^{o}(Y=H, S)$ is proposed; where $\Delta Y_{n a-c}^{o}$ is the estimated enthalpy or entropy for each one of 1a-c to 7a-c and $\Delta Y_{n a}^{o}$ is the enthalpy or entropy for each amide na as reference compound, thus $\Delta H_{H B}$ values for $\mathbf{2 b}$ are $\Delta H^{\circ}(\mathbf{2 b}) / \Delta H^{\circ}(\mathbf{2 a})=9.68 / 9.50=1.0$, for three centered hydrogen bonds, and for $\mathbf{2 c}, \Delta H^{\circ}(\mathbf{2} \mathbf{c}) / \Delta H^{\circ}(\mathbf{2 a})=12.92 / 9.50=1.4$ (Table 2), for cooperativity effects.

The enthalpy related to THB, $\Delta H_{H B}$ (b series), is significantly increased in relation to regular HB (a series) in compounds $\mathbf{4 b}$ and $\mathbf{5 b}$, it is slightly decreased in $\mathbf{7 b}$ and remains almost constant in the remaining compounds. Cooperativity effects on enthalpy are significant in compounds $\mathbf{2 c}$ and 5c. In contrast, the entropy $\Delta S_{H B}$ for both THB and cooperativity effects increases in 1-6 and is almost unchanged in $\mathbf{7}$. These results are in agreement with the expected increase in entropy due to the higher number of atoms involved in hydrogen bonding disruption, in regular $\mathrm{HB}$ there are

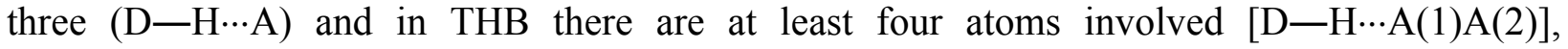
neglecting participation from solvent molecules. 
Table 2. Thermodynamic parameters and their standard errors obtained from van't Hoff plot for the N-H of compounds 1a-c to 7a-c

\begin{tabular}{lllllll}
\hline Comp. & $\Delta H^{o} / \mathrm{kJ} \mathrm{mol}^{-1}$ & $\Delta S^{o} / \mathrm{J} \mathrm{mol}^{-1} \mathrm{~K}^{-1}$ & $\Delta H_{A}$ & $\Delta S_{A}$ & $\Delta H_{H B}$ & $\Delta S_{H B}$ \\
\hline $\mathbf{1 a}$ & $9.57 \pm 0.02$ & $16.68 \pm 0.07$ & 1.0 & 1.0 & 1.0 & 1.0 \\
$\mathbf{1 b}$ & $11.82 \pm 0.08$ & $23.2 \pm 0.2$ & 1.0 & 1.0 & 1.2 & 1.4 \\
$\mathbf{1 c}$ & $11.49 \pm 0.02$ & $24.25 \pm 0.05$ & 1.0 & 1.0 & 1.2 & 1.5 \\
$\mathbf{2 a}$ & $9.50 \pm 0.03$ & $20.34 \pm 0.08$ & 1.0 & 1.2 & 1.0 & 1.0 \\
$\mathbf{2 b}$ & $9.68 \pm 0.08$ & $17.4 \pm 0.2$ & 0.8 & 0.8 & 1.0 & 0.9 \\
$\mathbf{2 c}$ & $12.92 \pm 0.09$ & $23.9 \pm 0.3$ & 1.1 & 1.0 & 1.4 & 1.2 \\
$\mathbf{3 a}$ & $10.78 \pm 0.05$ & $19.1 \pm 0.1$ & 1.1 & 1.1 & 1.0 & 1.0 \\
$\mathbf{3 b}$ & $11.90 \pm 0.04$ & $28.3 \pm 0.1$ & 1.0 & 1.2 & 1.1 & 1.5 \\
$\mathbf{3 c}$ & $12.00 \pm 0.04$ & $33.4 \pm 0.1$ & 1.0 & 1.4 & 1.1 & 1.7 \\
$\mathbf{4 a}$ & $9.93 \pm 0.04$ & $22.2 \pm 0.1$ & 1.0 & 1.3 & 1.0 & 1.0 \\
$\mathbf{4 b}$ & $15.3 \pm 0.07$ & $32.5 \pm 0.2$ & 1.3 & 1.4 & 1.5 & 1.5 \\
$\mathbf{4 c}$ & $13.6 \pm 0.1$ & $26.8 \pm 0.4$ & 1.2 & 1.1 & 1.4 & 1.2 \\
$\mathbf{5 a}$ & $8.30 \pm 0.02$ & $18.0 \pm 0.05$ & 0.9 & 1.1 & 1.0 & 1.0 \\
$\mathbf{5 b}$ & $14.6 \pm 0.05$ & $38.6 \pm 0.1$ & 1.2 & 1.7 & 1.8 & 2.1 \\
$\mathbf{5 c}$ & $21.1 \pm 0.2$ & $58.1 \pm 0.5$ & 1.8 & 2.4 & 2.5 & 3.2 \\
$\mathbf{6 a}$ & $11.41 \pm 0.09$ & $13.9 \pm 0.3$ & 1.2 & 0.8 & 1.0 & 1.0 \\
$\mathbf{6 b}$ & $13.47 \pm 0.04$ & $29.3 \pm 0.1$ & 1.1 & 1.3 & 1.2 & 2.1 \\
$\mathbf{6 c}$ & $14.95 \pm 0.15$ & $35.24 \pm 0.46$ & 1.3 & 1.5 & 1.3 & 2.5 \\
7a & $11.37 \pm 0.07$ & $22.1 \pm 0.2$ & 1.2 & 1.3 & 1.0 & 1.0 \\
7b & $8.6 \pm 0.1$ & $23.2 \pm 0.3$ & 0.7 & 1.0 & 0.8 & 1.0 \\
7c & $9.00 \pm 0.01$ & $20.26 \pm 0.03$ & 0.8 & 0.8 & 0.8 & 0.9 \\
\hline
\end{tabular}

$\Delta Y_{A}=\Delta Y_{n a-d}^{o} \Delta Y^{o}{ }_{1 a-c} ; \Delta Y_{H B}=\Delta Y_{n a-d}^{o} \Delta Y_{n a}^{o} ; Y=H, S$.

\section{Solvent effects on solution conformation}

In addition to the chemical shift temperature gradient $(\Delta \delta \mathrm{NH} / \Delta T)$, the solvent effect on $\mathrm{NH}$ chemical shift has also been accepted, as a general test for proton mobility, ${ }^{12}$ whose limitation is the inherent solubility of compounds. However, in the case of certain functional groups, the dielectric constant of the solvent could favor the participation of one preferred resonance structure over others. ${ }^{25,26}$ To contrast both tests, the ${ }^{1} \mathrm{H}$ NMR spectra of compounds 1a-c, 2a,b and $\mathbf{5 a}, \mathbf{b}$ were recorded in $\mathrm{CDCl}_{3}$ solution and compared with those recorded in DMSO-d6 solution. Results are listed in Table 3 for N-H and $\mathrm{H}(6)$ signals which showed significant variations in their chemical shift. The lack of data for compounds $\mathbf{2 c}$ and $\mathbf{5 c}$ are due to their insolubility in $\mathrm{CDCl}_{3}$. In general, the $\delta \mathrm{NH}$ in $\mathrm{CDCl}_{3}$ solutions is shifted to lower frequencies relative to DMSO solutions, in most of compounds except in 5b. Larger $\Delta \delta \mathrm{NH}$ values $\left[\delta \mathrm{NH}(\mathrm{DMSO})-\delta \mathrm{NH}\left(\mathrm{CDCl}_{3}\right)\right]$ were observed for compounds 1a-c with $\Delta \delta \mathrm{NH}$ values between 2.31 and $2.86 \mathrm{ppm}$, meaning that the intramolecular $\mathrm{N}-\mathrm{H} \cdots \mathrm{O}=\mathrm{C}$ interaction does not play an 
important role in fixing the $\mathrm{NH}$ proton in comparison with regular $\mathrm{HB}$ in amides, since $\Delta \delta \mathrm{NH}$ for 2a and 5a is smaller. However, the combined effects of $\mathrm{N}-\mathrm{H} \cdots \mathrm{A}, \mathrm{C}(6)-\mathrm{H} \cdots \mathrm{O}=\mathrm{C}$ and $\mathrm{N}-\mathrm{H} \cdots \mathrm{O}=\mathrm{C}$ interactions to form THB (2b and $\mathbf{5 b})$ have the effect of almost fixing the NH.

Table 3. Solvent effects data on $\delta \mathrm{NH}$ and $\delta \mathrm{H}(6)$ for compounds 1a-c, 2a-c and 5a-c

\begin{tabular}{llllllll}
\hline Comp. & $\begin{array}{l}\delta \mathrm{NH} \\
\left(\mathrm{CDCl}_{3}\right)\end{array}$ & $\begin{array}{l}\delta \mathrm{NH} \\
(\mathrm{DMSO})\end{array}$ & $\Delta \delta \mathrm{NH}$ & $\begin{array}{l}{ }^{1} \mathrm{~J}(\mathrm{~N}, \mathrm{H})^{\mathrm{a}} \\
(\text { hertz })\end{array}$ & $\begin{array}{l}\delta \mathrm{H}(6) \\
\left(\mathrm{CDCl}_{3}\right)\end{array}$ & $\begin{array}{l}\delta \mathrm{H}(6) \\
(\mathrm{DMSO})\end{array}$ & $\Delta \delta \mathrm{H}(6)$ \\
\hline $\mathbf{1 a}$ & 7.64 & 9.95 & 2.31 & 90.0 & 7.50 & 7.60 & 0.10 \\
$\mathbf{1 b}$ & 8.89 & 11.39 & 2.50 & 91.3 & 7.65 & 7.74 & 0.09 \\
$\mathbf{1 c}$ & 9.40 & 12.26 & 2.86 & 92.0 & 7.69 & 8.31 & 0.62 \\
$\mathbf{2 a}$ & 7.77 & 9.12 & 1.35 & 91.6 & 8.36 & 7.92 & -0.44 \\
$\mathbf{2 b}$ & 9.51 & 9.66 & 0.15 & 92.4 & 8.41 & 8.02 & -0.39 \\
$\mathbf{2 c}$ & & 9.88 & & 93.0 & & 8.13 & \\
$\mathbf{5 a}$ & 10.34 & 10.30 & -0.04 & 91.6 & 8.77 & 7.57 & -1.20 \\
$\mathbf{5 b}$ & 11.94 & 11.39 & -0.55 & 92.8 & 8.84 & 8.11 & -0.73 \\
$\mathbf{5 c}$ & & 11.79 & & & & 8.36 & \\
\hline
\end{tabular}

(a) Measured from ${ }^{1} \mathrm{NMR}$ spectra. (b) Very insoluble in $\mathrm{CDCl}_{3}$. (c) Completely insoluble in $\mathrm{CDCl}_{3}$ and slightly soluble in DMSO.

In oxalamate and bis-oxalamide systems, the participation of $\mathrm{C}(6)-\mathrm{H} 6 \cdots \mathrm{OCNH}$ hydrogen bonding as a cooperative interaction in THB formation, has been noted in both solution and in the solid state. ${ }^{18}$ In solution, the $\delta \mathrm{H}(6)$ is shifted to high frequencies by the local deshielding effect of the amide carbonyl group, which is most of the time pointing out to this hydrogen atom as the N-H mobility is smaller. This effect has been known for a long time for ortho-substituted anilides. ${ }^{27}$ The $\delta \mathrm{H}(6)$, also in $\mathrm{CDCl}_{3}$ solutions, is shifted to low frequencies in 1a-c but shifted to high frequencies in compounds $\mathbf{2 a}, \mathbf{b}$ and $\mathbf{5 a}, \mathbf{b}$. These results are interpreted in terms of a change in the preferred conformation of the $\mathrm{HNCO}$ group in solution. In the case of amide $\mathbf{2 a}$, in $\mathrm{CDCl}_{3}$ solution, the carbonyl group is most of the time in the same side of the $\mathrm{H}(6)$ proton $[\delta \mathrm{H}(6)=$ $8.36, \Delta \delta \mathrm{H}(6)=-0.44$ ], thus the rotamer I accounts for the strong deshielding of $\mathrm{H}(6)$, but this position does not necessarily fix the $\mathrm{NH}$ proton as is indicated by $\delta \mathrm{NH}$ value of 7.77 and the large $\Delta \delta \mathrm{NH}$ value of 1.35 . In contrast, the amide 5a, shows a large change in $\Delta \delta \mathrm{H}(6)$ of -1.20 but very small change in $\Delta \delta \mathrm{NH}=-0.04$. These observations can be explained taking into account the solvent effect in the stabilization of more polar canonical forms as its dielectric constant is increased. 


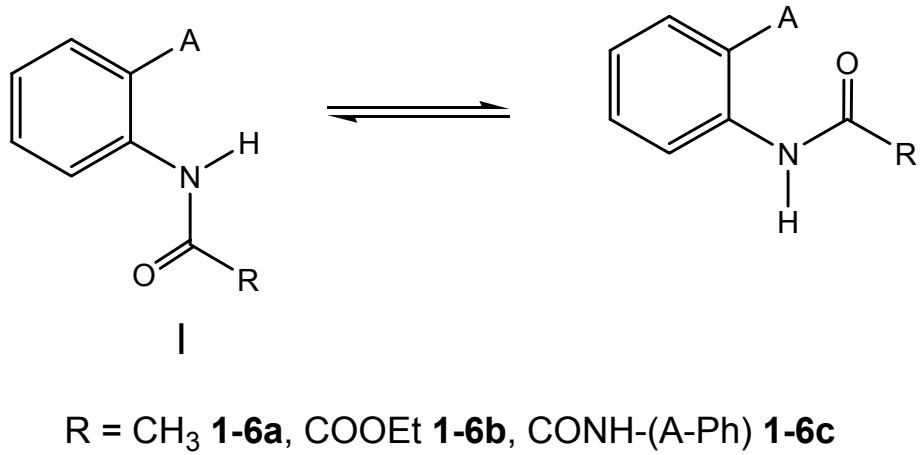

\section{Rotational barrier contribution to hydrogen bonding}

The signal of $\mathrm{H}(6)$ is shifted to high frequencies when the temperature is raised in compounds 5a-c. In the rest of them $\delta \mathrm{H}(6)$ remains unchanged. As stated before, the rotational barrier of the $\mathrm{Ph}-\mathrm{NH}$ bond could be increased due to the electron-withdrawing effect of the $o-\mathrm{NO}_{2}$ group in the phenyl ring, favoring a double bond character $\left(\mathrm{Ph}=\mathrm{NH}^{+}\right)$. The temperature rise provides the energy required to the free rotation of $\mathrm{Ph}-\mathrm{N}$ bond, thus data related to $\Delta \delta \mathrm{H}(6) / \Delta T$ allowed us to estimate the thermodynamic parameters of associated with the rotation of this bond. $\Delta \delta \mathrm{H}(6) / \Delta T$ values and related NLFP and van't Hoff data are recorded in Table 4. Predicted $\delta_{\mathrm{LT}}$ and $\delta_{\mathrm{HT}}$ chemical shifts for $\mathrm{H}(6)$ in compounds $\mathbf{5 b}$ and $\mathbf{5 c}$ are in agreement with the expected THB formation in both compounds. The equilibrium is shifted to more double bond order $\mathrm{Ph}=\mathrm{NH}^{+}$ character for compound $\mathbf{5} \mathbf{c}$ followed by $\mathbf{5 b}$ and finally the amide $\mathbf{5 a}$. The estimated $\Delta H^{\circ}$ and $\Delta \mathrm{S}^{\circ}$ for the process are smaller for the amide than for both oxalamate $\mathbf{5 b}$ and bis-oxalamide $\mathbf{5 c}$. These data allowed the estimation of the $\mathrm{Ph}=\mathrm{NH}^{+}$rotational barrier of $14.0,18.0$ and $16.7 \mathrm{~kJ} \mathrm{~mol}^{-1}$ for $\mathbf{5 a}, \mathbf{5 b}$, and $\mathbf{5 c}$, respectively, from van't Hoff data.

Table 4. Temperature gradient of the chemical shift $(\Delta \delta / \Delta T)$, estimated parameters from NLFP, van't Hoff data and their standard errors for H(6) in compounds 5a-c

\begin{tabular}{lccccccc}
\hline \multicolumn{5}{c}{ NLFP data } & \multicolumn{3}{c}{ van't Hoff data } \\
\hline Comp. & $\begin{array}{c}-(\Delta \delta / \Delta T) / \\
\mathrm{ppb} \mathrm{K}{ }^{-1}\end{array}$ & $K_{303}$ & $\delta_{L \mathrm{~T}} / \mathrm{ppm}$ & $\delta_{H T} / \mathrm{ppm}$ & $\begin{array}{c}\Delta H^{o} / \\
\mathrm{kJ} \mathrm{mol}^{-1}\end{array}$ & $\begin{array}{c}\Delta H^{o} / \\
\mathrm{kJ} \mathrm{mol}^{-1}\end{array}$ & $\begin{array}{c}\Delta S^{o} / \\
\mathrm{J} \mathrm{mol}^{-1} \mathrm{~K}^{-1}\end{array}$ \\
\hline $\mathbf{5 a}$ & $2.70 \pm 0.06$ & $0.47 \pm 0.02$ & $7.50 \pm 0.08$ & $8.27 \pm 0.03$ & $14.0 \pm 0.4$ & $13.93 \pm 0.08$ & $39.6 \pm 0.2$ \\
$\mathbf{5 b}$ & $1.29 \pm 0.06$ & $0.7 \pm 0.1$ & $8.01 \pm 0.04$ & $8.5 \pm 0.03$ & $18.0 \pm 0.2$ & $18.02 \pm 0.12$ & $56.6 \pm 0.4$ \\
$\mathbf{5 c}$ & $1.44 \pm 0.08$ & $1.9 \pm 0.1$ & $8.12 \pm 0.02$ & $8.472 \pm 0.005$ & $16.8 \pm 0.5$ & $16.66 \pm 0.09$ & $56.3 \pm 0.3$ \\
\hline
\end{tabular}

\section{Relation between thermodynamic parameters and $\Delta \delta / \Delta T$}

In an effort to relate the temperature gradients of the amide $\mathrm{NH}$ chemical shift with the estimated thermodynamic parameters, $\Delta \delta \mathrm{NH} / \Delta T$ values were correlated with the estimated $\Delta H^{\circ}$ and $\Delta S^{\circ}$ values for the hydrogen bonding disruption process. After the removal of data points concerning compounds $\mathbf{2 b}$ and $\mathbf{2 c}, \Delta H^{\circ}$ showed significant correlation with chemical shift temperature gradient values, for both oxalamate (Figure $2 \mathrm{~b}$ ) and bis-oxalamide series (Figure $2 \mathrm{c}$ ) $\left[\Delta H^{\circ} \mathbf{b}=\right.$ 
$18.7(1.0)-1.4(0.2)|\Delta \delta \mathrm{NH} / \Delta T|, R=0.9511 ; \Delta H^{\circ}{ }_{\mathbf{c}}=24.4(1.7)-2.6(0.4)|\Delta \delta \mathrm{NH} / \Delta T|, R=0.9585$, estimated error in brackets], whereas no correlation was found for amides (Figure 2a). These results are in agreement with low energy requirements for hydrogen bonding disruption at high $\Delta \delta \mathrm{NH} / \Delta T$ values. In oxalamate and oxalamide series, $\Delta H^{\circ}$ values register a decrease of $1.4(0.2)$ and 2.6(0.4) $\mathrm{kJ} \mathrm{mol}^{-1}$, respectively, for each unit of $|\Delta \delta \mathrm{NH} / \Delta T|$ change in $\mathrm{ppb} \mathrm{K}^{-1}$. The larger value for the slope in bis-oxalamide $\mathbf{c}$ series than in oxalamate $\mathbf{b}$ series is in agreement with the participation of cooperative effects on THB formation in the former. The linear equations predict an enthalpy change of $18.7(1.0)$ and $24.4(1.7) \mathrm{kJ} \mathrm{mol}^{-1}$ for the energy required to break a full $\mathrm{THB}(|\Delta \delta \mathrm{NH} / \Delta T|=0)$ in oxalamate and bis-oxalamide series, respectively.

Correlations between entropy and $\Delta \delta \mathrm{NH} / \Delta T$ values were done after the exclusion of data points for compounds $\mathbf{4 a}, \mathbf{2 b}$ and $\mathbf{2 c}$. The entropy difference between non-bonded and hydrogen bonded states increases as $\Delta \delta \mathrm{NH} / \Delta T$ values increase for amides [Figure $2 \mathrm{~d} ; \Delta S_{\mathbf{a}}^{\circ}=6.5(1.8)+$ $2.8(0.4)|\Delta \delta \mathrm{NH} / \Delta T|, R=0.9573]$ meaning that high values of $\Delta \delta \mathrm{NH} / \Delta T$ correspond to a more disordered system in the final state. This result is in agreement with $\mathrm{NH}$ solvent exchange, because the internal hydrogen bond disrupts at the expense of at least one hydrogen bond formation with the solvent. For both oxalamate and bis-oxalamide series the small values of $\Delta \delta \mathrm{NH} / \Delta T$ are associated with large entropic differences between non-bonded and hydrogen bonded states. The conformational restraints imposed by a strong THB should lead to an increased entropic barrier to its disruption by solvent. $\Delta S^{\circ}$ for $\mathbf{b}$ [Figure $2 \mathrm{~d} ; \Delta S_{\mathbf{b}}^{\circ}=42.0(4.7)-$ $2.9(1.0)|\Delta \delta \mathrm{NH} / \Delta T|, R=0.8215]$ and $\mathbf{c}$ series [Figure 2f; $\Delta S^{\circ}{ }_{\mathbf{c}}=61.9(11)-7.2(2.6)|\Delta \delta \mathrm{NH} / \Delta T|$, $R=0.8149]$ is less well correlated with $\Delta \delta \mathrm{NH} / \Delta \mathrm{T}$ values than the corresponding $\Delta S^{\circ}$ values for a series. Nevertheless, some tendencies can be outlined, the slope $\Delta S^{\circ} /|\Delta \delta \mathrm{NH} / \Delta T|$ is larger than slope $\Delta S_{\mathbf{b}}^{\circ}|\Delta \delta \mathrm{NH} / \Delta T|$, thus the entropy decreases in 2.9(1.0) and 7.2(2.6) $\mathrm{J} \mathrm{mol}^{-1} \mathrm{~K}^{-1}$ by each unit of change in $|\Delta \delta \mathrm{NH} / \Delta T|$ in ppb $\mathrm{K}^{-1}$ for $\mathbf{b}$ and $\mathbf{c}$ series, respectively, and for full hydrogen bonded system $(|\Delta \delta \mathrm{NH} / \Delta T|=0)$ an entropy differences between non hydrogen bonded and hydrogen bonded state of 42.0(4.7) and 61.9(11) $\mathrm{J} \mathrm{mol}^{-1} \mathrm{~K}^{-1}$ are predicted for $\mathbf{b}$ and $\mathbf{c}$ series, respectively. These results are in agreement with a multiple site solvation model ${ }^{22}$ in which the solvent molecules are ordered around THB as an intermediate step in the proton transfer process. It should be noted that the points out of correlation were those corresponding to compounds $\mathbf{2} \mathbf{b}$, $\mathbf{2 c}$ and, in the case of entropy, $\mathbf{4 a}$; the last compound possesses an exchangeable $\mathrm{O}-\mathrm{H}$ proton that could be the reason for the lack of correlation between the estimated thermodynamic parameters and the experimental $|\Delta \delta \mathrm{NH} / \Delta T|$ measurements. In the case of the first pair of compounds, corresponding to $\mathrm{A}=\mathrm{OMe}$ in a five membered hydrogen bonding ring environment, the measured $|\Delta \delta \mathrm{NH} / \Delta \mathrm{T}|$ values are very small and the estimated values of $\Delta H^{\circ}$ and $\Delta S^{\circ}$ are also small and thus they do not fit with the experimental trend. The low values of $|\Delta \delta \mathrm{NH} / \Delta T|$ in compounds 2b-ce, can be explained in terms of a deeply buried $\mathrm{NH}$ inside a chemical environment strongly stabilized by the favorable attraction between antiparallel dipoles ${ }^{24}$ and $\mathrm{C}(6)-\mathrm{H} \cdots \mathrm{O}=\mathrm{CO}$ soft hydrogen bonding interaction. Thus, $|\Delta \delta \mathrm{NH} / \Delta T|$ values seem to be more related with kinetics ${ }^{28}$ than with thermodynamic parameters in compounds $\mathbf{2 b - c}$. Finally, the 
results obtained herein point to the energetic superiority of THB disruption than for regular HB, and the participation of cooperative effects in the former.

\section{Conclusions}

The HB disruption by solvent molecules is a complex process because it also includes rotational barriers, effects of the substituents on the NH acidity and conformational preferences, among others. The applied methodology gave valuable information of the process as a whole, even when it is was not possible to evaluate the individual contributions to the energy. Nevertheless the predicted $\delta_{H B}$ values are in agreement with the expected regular HB state for the amide and THB state for oxalamate and bis-oxalamide series. The influence of the ortho-acceptor group (A) is more important when electron-withdrawing, increasing the enthalpy required to disrupt both $\mathrm{HB}$ and THB, but in both cases the entropy is increased, as expected. A brief comparison between $\mathrm{N}-\mathrm{H}$ and $\mathrm{H}(6)$ chemical shifts in $\mathrm{CDCl}_{3}$ and DMSO-d6 solutions suggest that in the former the more polar canonical forms of amide-carbonyl moiety are present. The HNCO group modifies its conformation in solution, as was monitored by $\Delta \delta \mathrm{H}(6) / \Delta T$ to high frequencies in $\mathrm{NO}_{2}$ derivatives (5a-c). These data allowed the estimation of the $\mathrm{Ph}=\mathrm{NH}^{+}$rotational barrier of 14.0, 18.0 and $16.7 \mathrm{~kJ} \mathrm{~mol}^{-1}$ in $\mathbf{5 a}, \mathbf{5 b}$ and $\mathbf{5 c}$, respectively. $\Delta H^{\circ}$ values decrease $1.4(0.2)$ and $2.6(0.4) \mathrm{kJ} \mathrm{mol}^{-1}$, for $|\Delta \delta \mathrm{NH} / \Delta \mathrm{T}|$ unit of change in $\mathrm{ppb} \mathrm{K}^{-1}$ and take a value of 18.7(1.0) and $24.4(1.7) \mathrm{kJ} \mathrm{mol}^{-1}$, corresponding to the energy required to break a full THB $(|\Delta \delta \mathrm{NH} / \Delta T|=0)$ in oxalamate $\mathbf{b}$ and oxalamide $\mathbf{c}$ series, respectively; $\Delta S^{\circ}$ values decrease in 2.9(1.0) and 7.2(2.6) $\mathrm{J}$ $\mathrm{mol}^{-1} \mathrm{~K}^{-1}$ by $|\Delta \delta \mathrm{NH} / \Delta \mathrm{T}|$ unit of change, and 42.0(4.7) and 61.9(11) $\mathrm{J} \mathrm{mol}^{-1} \mathrm{~K}^{-1}$ are predicted for full hydrogen bonded system in oxalamate $\mathbf{b}$ and oxalamide $\mathbf{c}$ series, respectively. The results are in agreement with the expected values for the energetic superiority of TBH in $o$-aromatic oxalamates and oxalamides, in relation to regular $\mathrm{HB}$, and support the participation of cooperative effects. 

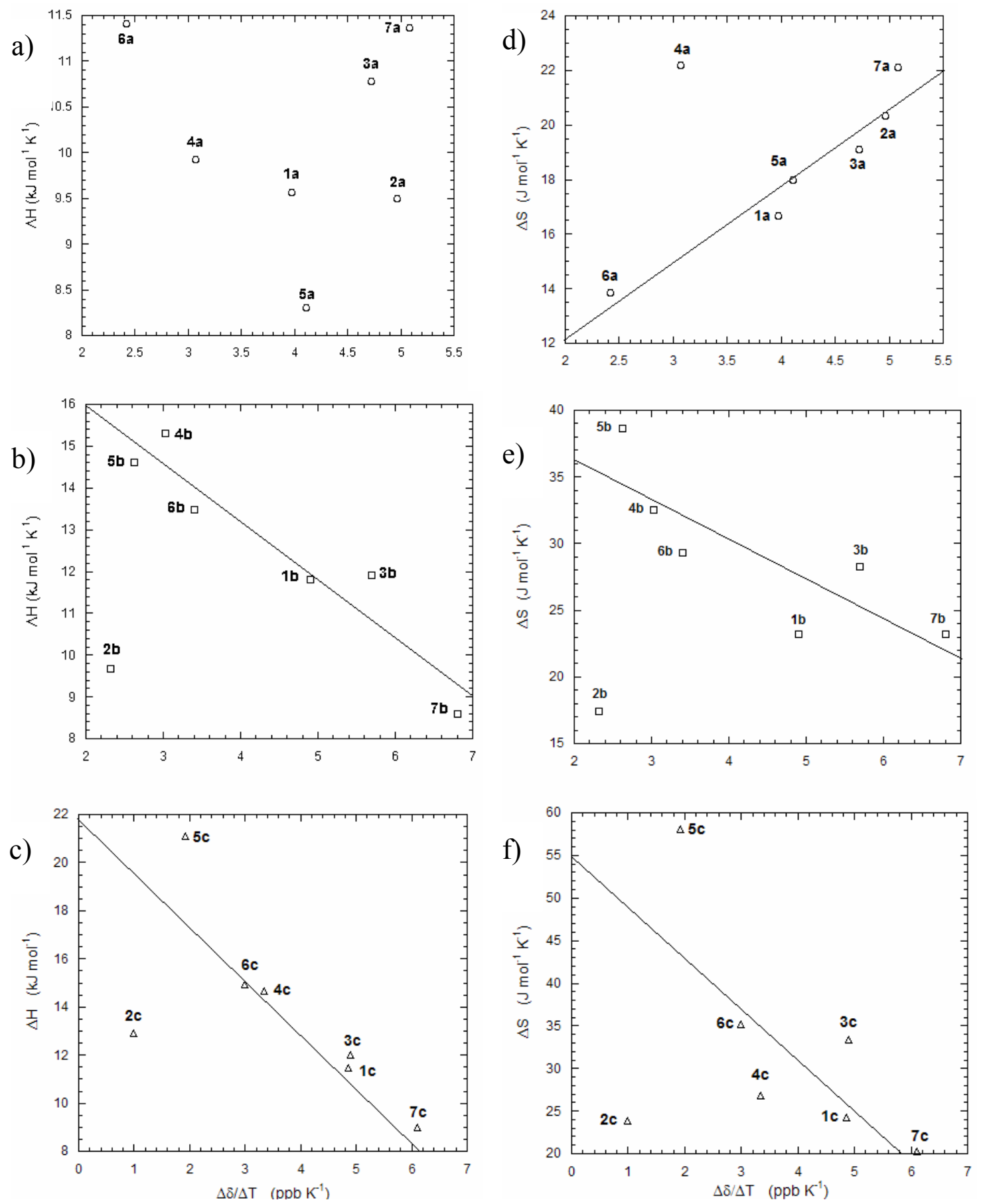

Figure 2. $\Delta H^{\circ}$ and $\Delta S^{\circ}$ dependence of $\mathrm{N}-\mathrm{H}$ chemical shifts temperature gradients. Left $\Delta H^{\circ}$, and right $\Delta S^{\circ}$ for $\mathbf{a}, \mathbf{b}$ and $\mathbf{c}$ series. The absolute value of $-\Delta \delta / \Delta T$ is plotted in the $x$ axis. $\Delta H_{\mathbf{b}}=$ $18.7(1.0)-1.4(0.2)|\Delta \delta / \Delta T|(R=0.9511) ; \Delta H_{\mathbf{c}}=24.4(1.7)-2.6(0.4)|\Delta \delta / \Delta T|(R=0.9585) ; \Delta S_{\mathbf{a}}=$ $6.5(1.8)+2.8(0.4)|\Delta \delta / \Delta T|(R=0.9573) ; \Delta S_{\mathbf{b}}=42.0(4.7)-2.9(1.0)|\Delta \delta / \Delta T|(R=0.8215) ; \quad \Delta S_{\mathbf{c}}=$ $61.9(11)-7.2(2.6)|\Delta \delta / \Delta T|(R=0.8149)$; estimated error in brackets. 


\section{Experimental Section}

General Procedures. Acetanilide 1a, aniline, 2-methoxybenzylamine, 2-fluoroaniline, (2aminophenyl)methanol, 1-(2-aminophenyl)ethanone, 2-methoxymethylaniline, acetyl chloride, ethyl chlorooxoacetate and oxalyl chloride were purchased from Aldrich and used as received. Elemental analyses were performed in a Perkin-Elmer 2400 elemental analyzer. Melting points were measured on an Electrothermal IA 9100 apparatus and were uncorrected. IR spectra were recorded in $\mathrm{KBr}$ disks using a Perkin-Elmer $16 \mathrm{~F}$ PC IR spectrophotometer. ${ }^{1} \mathrm{H}$ and ${ }^{13} \mathrm{C}$ NMR spectra were recorded on a Varian Mercury $300(300.8 \mathrm{MHz})$ equipment in $\left[{ }^{2} \mathrm{H}_{6}\right] \mathrm{DMSO}$ or $\mathrm{CDCl}_{3}$ solutions. Chemical shifts are reported in ppm and coupling constants in Hz. COSY, APT and HETCOR experiments were performed to unequivocally assign ${ }^{1} \mathrm{H}$ and ${ }^{13} \mathrm{C}$ NMR signals, and NOE experiments on amide NH to assign H6 signal, using standard techniques. Variable temperature experiments were performed with a temperature controller to keep temperature constant within $0.2{ }^{\circ} \mathrm{C}$. A microprogram was used to change temperature automatically in $10^{\circ} \mathrm{C}$ increments with a delay of $5 \mathrm{~min}$ for the temperature stabilization. Each spectrum was obtained with 32 scans. Samples concentration was maintained at $5 \mathrm{mg} / 0.4 \mathrm{~mL}$ or less in $\left[{ }^{2} \mathrm{H}_{6}\right] \mathrm{DMSO}$ solutions. Temperature controller was calibrated using standard techniques given by the purchaser.

\section{General preparative procedures}

Compounds 1a-c, 2a-c, 3a-c, 4a-c, 5a-c, 6a-c and 7a-c were prepared according to previously reported procedures starting from the corresponding amine and acetyl chloride, ethyl chlorooxoacetate or oxalyl chloride. Characterization of compounds $\mathbf{1 b}$ and $\mathbf{1 c},{ }^{29} \mathbf{2 a}$ and $\mathbf{2 c},{ }^{1} \mathbf{2 b}$ and $\mathbf{4 c},{ }^{18} \mathbf{3 a},{ }^{30} \mathbf{3 b},{ }^{31} \mathbf{5} \mathbf{b}^{19}$ and $\mathbf{6} \mathbf{a}^{32}$ by ${ }^{1} \mathrm{H}$ and ${ }^{13} \mathrm{C}$ NMR, IR and melting points were in agreement with reported data. ${ }^{1} \mathrm{H}$ and ${ }^{13} \mathrm{C}$ NMR in $\left[{ }^{2} \mathrm{H}_{6}\right] \mathrm{DMSO}$ solutions (only $\mathbf{6 c}$ in $\mathrm{CDCl}_{3}$ ), IR and melting points of compounds $3 \mathbf{c}, \mathbf{4 a}, \mathbf{4 b}, \mathbf{5 c}, \mathbf{6 b}-\mathbf{c}, 7 \mathbf{a}-\mathbf{c}$ are herein reported.

$\boldsymbol{N}, N^{\prime}$-bis[(2-Fluoro)phenyl]oxalamide (3c). Obtained from 2-fluoroaniline and ethyl oxalyl chloride as a white crystalline solid in $30 \%$ yield, m.p. $=208{ }^{\circ} \mathrm{C},{ }^{1} \mathrm{H}$ NMR $(\delta): 10.68(\mathrm{~s}, 1 \mathrm{H}$, $\mathrm{NH}), 7.79(\mathrm{~m}, 1 \mathrm{H}, \mathrm{H} 6), 7.44(\mathrm{~m}, 3 \mathrm{H}, \mathrm{H} 3-5) .{ }^{13} \mathrm{C} \mathrm{NMR}(\delta): 159.0(\mathrm{~s}, \mathrm{C}=\mathrm{O}), 155.9\left(\mathrm{~d}, \mathrm{~J}_{\mathrm{C}-\mathrm{F}}=\right.$ 247.5, C2), $128.3\left(\mathrm{dd}, \mathrm{J}_{\mathrm{C}-\mathrm{F}}=7.8, \mathrm{C} 4\right), 126.8(\mathrm{~d}, \mathrm{C} 5), 125.2\left(\mathrm{dd}, \mathrm{J}_{\mathrm{C}-\mathrm{F}}=3.3, \mathrm{C} 6\right), 125.0\left(\mathrm{~d}, \mathrm{~J}_{\mathrm{C}-\mathrm{F}}=\right.$ 12.2, C1), $116.6\left(\mathrm{dd}, \mathrm{J}_{\mathrm{C}-\mathrm{F}}=18.9, \mathrm{C} 3\right)$. IR $\left(\mathrm{cm}^{-1}\right): 3313(\mathrm{vs}, \mathrm{NH}), 1678(\mathrm{vs}, \mathrm{C}=\mathrm{O})$. EA for $\mathrm{C}_{14} \mathrm{H}_{10} \mathrm{~F}_{2} \mathrm{O}_{2} \mathrm{~N}_{2}$ found (\%) (required): C 60.6 (60.9), H 3.6 (3.7), N 9.9 (10.1).

$\mathrm{N}$-[(2-Hydroxymethyl)phenyl]acetamide (4a). Obtained from (2-aminophenyl)methanol and acetyl chloride in $84 \%$ yield, as a white solid after recrystallization from toluene solution m.p. $=$ $116{ }^{\circ} \mathrm{C} .{ }^{1} \mathrm{H}$ NMR $(\delta): 9.29$ (s, 1H, NH), 7.46 (d, 1H, $\left.{ }^{3} \mathrm{~J}=7.4, \mathrm{H} 6\right), 7.39$ (d, 1H, $\left.{ }^{3} \mathrm{~J}=7.4, \mathrm{H} 3\right)$, $7.19\left(\mathrm{dd}, 1 \mathrm{H},{ }^{3} \mathrm{~J}=7.8,{ }^{3} \mathrm{~J}=7.4, \mathrm{H} 5\right), 7.12\left(\mathrm{dd}, 1 \mathrm{H},{ }^{3} \mathrm{~J}=7.6,{ }^{3} \mathrm{~J}=7.2, \mathrm{H} 4\right), 5.4(\mathrm{~b}, 1 \mathrm{H}, \mathrm{OH}), 4.46$ $\left(\mathrm{s}, 2 \mathrm{H}, \mathrm{CH}_{2}\right), 2.03\left(\mathrm{~s}, 3 \mathrm{H}, \mathrm{CH}_{3}\right) .{ }^{13} \mathrm{C} \mathrm{NMR}(\delta): 169.0(\mathrm{~s}, \mathrm{C}=\mathrm{O}), 136.1(\mathrm{~s}, \mathrm{C} 1), 135.6(\mathrm{~s}, \mathrm{C} 2)$,

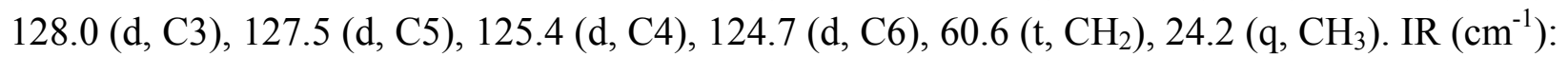
3276 (vs, OH), $3200(\mathrm{~s}, \mathrm{NH}), 1656(\mathrm{vs}, \mathrm{C}=\mathrm{O})$. $\mathrm{EA}$ for $\mathrm{C}_{9} \mathrm{H}_{11} \mathrm{O}_{2} \mathrm{~N}$ found (\%) (required): $\mathrm{C} 65.6$ (65.4), H 6.6 (6.7), N 8.1 (8.5). 
Ethyl $\boldsymbol{N}$-[(2-hydroxymethyl)phenyl]oxalamate (4b). Obtained from (2-aminophenyl)methanol and ethyl chlorooxoacetate in 95\% yield as a highly hygroscopic liquid. ${ }^{1} \mathrm{H}$ NMR $(\delta): 10.71$ (s, $1 \mathrm{H}, \mathrm{NH}), 7.84\left(\mathrm{dd}, 1 \mathrm{H},{ }^{4} \mathrm{~J}=1.0,{ }^{3} \mathrm{~J}=8.1, \mathrm{H} 6\right), 7.32\left(\mathrm{dt}, 1 \mathrm{H},{ }^{4} \mathrm{~J}=1.5,{ }^{3} \mathrm{~J}=7.5, \mathrm{H} 4\right), 7.28(\mathrm{dd}, 1 \mathrm{H}$, $\left.{ }^{4} \mathrm{~J}=1.6,{ }^{3} \mathrm{~J}=7.8, \mathrm{H} 3\right), 7.15\left(\mathrm{dd}, 1 \mathrm{H},{ }^{4} \mathrm{~J}=1.3,{ }^{3} \mathrm{~J}=7.2, \mathrm{H} 5\right), 4.56\left(\mathrm{~s}, 2 \mathrm{H}, \mathrm{CH}_{2}\right), 4.28\left(\mathrm{q}, 2 \mathrm{H},{ }^{3} \mathrm{~J}=\right.$ 7.1, $\left.\mathrm{OCH}_{2}\right), 1.29\left(\mathrm{t}, 3 \mathrm{H},{ }^{3} \mathrm{~J}=7.0, \mathrm{CH}_{3}\right) .{ }^{13} \mathrm{C} \mathrm{NMR}(\delta): 160.5(\mathrm{~s}, \mathrm{OC}=\mathrm{O}), 154.7(\mathrm{~s}, \mathrm{NC}=\mathrm{O}), 135.3$ (s, C2), 132.9 (s, C1), 128.0 (d, C3), 127.7 (d, C5), 125.2 (d, C4), 122.3 (d, C6), 62.7 (t, OCH OC, $^{2}$ $61.5\left(\mathrm{t}, \mathrm{CH}_{2}\right), 13.9$ (q, $\left.\mathrm{CH}_{3}\right)$. IR ( $\left.\mathrm{cm}^{-1}\right): 3497$ (vs, OH), $3247(\mathrm{~s}, \mathrm{NH}), 1735,1698$ (2vs, C=O). EA for $\mathrm{C}_{11} \mathrm{H}_{13} \mathrm{O}_{4} \mathrm{~N} \cdot 3 \mathrm{H}_{2} \mathrm{O}$ found (\%) (required): C 47.5 (47.7), $\mathrm{H} 6.6$ (6.9), $\mathrm{N} 4.9$ (5.1).

$\boldsymbol{N}, \boldsymbol{N}^{\prime}$-Bis[(2-nitro)phenyl]oxalamide (5c). Obtained from 2-nitroaniline and oxalyl chloride as a yellow powder m.p. $=335{ }^{\circ} \mathrm{C} .{ }^{1} \mathrm{H}$ NMR $(\delta): 11.68(\mathrm{~s}, 1 \mathrm{H}, \mathrm{NH}), 8.45\left(\mathrm{~d}, 1 \mathrm{H},{ }^{3} \mathrm{~J}=8.8, \mathrm{H} 6\right), 8.32$ $\left(\mathrm{d}, 1 \mathrm{H},{ }^{3} \mathrm{~J}=8.5, \mathrm{H} 3\right), 7.99\left(\mathrm{dd}, 1 \mathrm{H},{ }^{3} \mathrm{~J}=8.8,7.0, \mathrm{H} 5\right), 7.60\left(\mathrm{dd}, 1 \mathrm{H},{ }^{3} \mathrm{~J}=7.3,7.0, \mathrm{H} 4\right) .{ }^{13} \mathrm{C}$ NMR data is not available because of insolubility reasons. IR $\left(\mathrm{cm}^{-1}\right): 3424(\mathrm{~s}, \mathrm{NH}), 1709(\mathrm{vs}, \mathrm{C}=\mathrm{O})$. EA for $\mathrm{C}_{14} \mathrm{H}_{10} \mathrm{O}_{6} \mathrm{~N}_{4}$. found (\%) (required): C 50.9 (50.9), H 3.2 (3.1), N 16.6 (17.0).

Ethyl $\mathbf{N}$-(2-acetylphenyl)oxalamate (6b). Obtained from 1-(2-aminophenyl)ethanone and ethyl chlorooxoacetate as a white solid in $88 \%$ yield, m. p. $=118.7-120.2{ }^{\circ} \mathrm{C} .{ }^{1} \mathrm{H}$ NMR $(\delta): 12.8(\mathrm{~s}$, $1 \mathrm{H}, \mathrm{NH}), 8.58\left(\mathrm{~d}, 1 \mathrm{H},{ }^{3} \mathrm{~J}=8.4, \mathrm{H} 6\right), 8.12\left(\mathrm{~d}, 1 \mathrm{H},{ }^{3} \mathrm{~J}=7.9, \mathrm{H} 3\right), 7.68\left(\mathrm{t}, 1 \mathrm{H},{ }^{3} \mathrm{~J}=8.0, \mathrm{H} 4\right), 7.30(\mathrm{t}$, $\left.1 \mathrm{H},{ }^{3} \mathrm{~J}=8.5,7.9, \mathrm{H} 5\right), 4.30\left(\mathrm{q}, 2 \mathrm{H}, \mathrm{CH}_{2}\right), 2.66\left(\mathrm{~s}, 3 \mathrm{H}, \mathrm{COCH}_{3}\right), 1.31\left(\mathrm{~s}, 3 \mathrm{H}, \mathrm{CH}_{3}\right) .{ }^{13} \mathrm{C} \mathrm{NMR}(\delta)$ : $203.7(\mathrm{~s}, \mathrm{ArC}=\mathrm{O}), 160.5(\mathrm{~s}, \mathrm{OC}=\mathrm{O}), 155.4(\mathrm{~s}, \mathrm{NC}=\mathrm{O}), 138.6(\mathrm{~s}, \mathrm{C} 2), 135.5$ (d, C3), 133.2 (d, C5), 124.8 (d, C4), 123.8 (s, C1), 120.5 (d, C6), 64.0 (t, $\left.\mathrm{CH}_{2}\right), 28.0$ (q, $\left.\mathrm{OCH}_{3}\right), 18.0$ (q, $\left.\mathrm{CH}_{3}\right)$. IR $\left(\mathrm{cm}^{-1}\right)$ : $3154(\mathrm{w}, \mathrm{NH}), 1754,1703,1655$ (vs, 2s, C=O). EA for $\mathrm{C}_{12} \mathrm{H}_{13} \mathrm{O}_{4} \mathrm{~N} \cdot 0.5 \mathrm{H}_{2} \mathrm{O}$ found (\%) (required): C 59.3 (59.0), H 5.5 (5.8), N 5.8 (5.7).

$\boldsymbol{N}, \boldsymbol{N}$ '-Bis(2-acetylphenyl)oxalamide (6c). Obtained from 1-(2-aminophenyl)ethanone and oxalyl chloride as white crystals in 57\% yield, m. p. $=281.3-281.9{ }^{\circ} \mathrm{C} .{ }^{1} \mathrm{H} \mathrm{NMR}\left(\mathrm{CDCl}_{3}, \delta\right): 13.3$ (s, 1H, NH), $8.91\left(\mathrm{dd}, 1 \mathrm{H},{ }^{4} \mathrm{~J}=1.5,{ }^{3} \mathrm{~J}=8.5, \mathrm{H} 6\right), 7.97\left(\mathrm{dd}, 1 \mathrm{H},{ }^{4} \mathrm{~J}=1.5,{ }^{3} \mathrm{~J}=7.9, \mathrm{H} 3\right), 7.63$ (ddd, $\left.1 \mathrm{H},{ }^{4} \mathrm{~J}=1.5,{ }^{3} \mathrm{~J}=7.3,{ }^{3} \mathrm{~J}=8.8, \mathrm{H} 5\right), 7.24\left(\mathrm{ddd}, 1 \mathrm{H},{ }^{4} \mathrm{~J}=1.2,{ }^{3} \mathrm{~J}=7.6, \mathrm{H} 4\right), 2.27\left(\mathrm{~s}, 3 \mathrm{H}, \mathrm{CH}_{3}\right) .{ }^{13} \mathrm{C}$ NMR $\left(\mathrm{CDCl}_{3}, \delta\right): 202.3$ (s, ArC=O), 159.1 (s, NC=O), 139.2 (s, C2), 135.2 (d, C3), 131.9 (d, C5), 124.0 (d, C4), 123.4 (s, C1), 121.2 (d, C6) 28.0 (q, CH3). IR (cm $\left.{ }^{-1}\right): 3145$ (w, NH), 1695 (sh), 1686, 1664, $1653(3 \mathrm{~s}, \mathrm{C}=\mathrm{O})$. $\mathrm{EA}$ for $\mathrm{C}_{18} \mathrm{H}_{16} \mathrm{O}_{4} \mathrm{~N}_{2}$ found (\%) (required): $\mathrm{C} 66.5$ (66.7), $\mathrm{H} 4.9$ (5.0), N 8.4 (8.6).

$\mathrm{N}$-[(2-Methoxy)benzyl]acetamide (7a). Obtained from 2-methoxymethylaniline and acetyl chloride as a white powder in $91 \%$ yield, m.p. $=93{ }^{\circ} \mathrm{C} .{ }^{1} \mathrm{H}$ NMR $(\delta): 8.23(\mathrm{~b}, 1 \mathrm{H}, \mathrm{NH}), 7.35(\mathrm{dt}$, $\left.1 \mathrm{H},{ }^{4} \mathrm{~J}=1.5,{ }^{3} \mathrm{~J}=7.7, \mathrm{H} 4\right), 7.27\left(\mathrm{dd}, 1 \mathrm{H},{ }^{4} \mathrm{~J}=1.3,{ }^{3} \mathrm{~J}=7.2, \mathrm{H} 6\right), 7.08\left(\mathrm{~d}, 1 \mathrm{H},{ }^{3} \mathrm{~J}=8.1, \mathrm{H} 3\right), 7.02$ $\left(\mathrm{dt}, 1 \mathrm{H},{ }^{4} \mathrm{~J}=0.7,{ }^{3} \mathrm{~J}=7.4, \mathrm{H} 5\right), 4.32\left(\mathrm{~d}, 2 \mathrm{H},{ }^{3} \mathrm{~J}=5.9, \mathrm{CH}_{2}\right), 3.91\left(\mathrm{~s}, 3 \mathrm{H}, \mathrm{OCH}_{3}\right), 1.99(\mathrm{~s}, 3 \mathrm{H}$, $\left.\mathrm{CH}_{3}\right) .{ }^{13} \mathrm{C}$ NMR $(\delta): 169.3$ (s, C=O), 156.7 (s, C2), 128.1 (d, C4), 127.8 (d, C6), 127.0 (s, C1), 120.2 (d, C5), 110.5 (d, C3), 55.4 (t, $\mathrm{CH}_{2}$ ), 37.2 (q, $\left.\mathrm{OCH}_{3}\right), 22.7$ (q, $\left.\mathrm{CH}_{3}\right) . \mathrm{IR}\left(\mathrm{cm}^{-1}\right): 3290$ (vs, $\mathrm{NH}$ ), 1655 (vs, $\mathrm{C}=\mathrm{O}$ ). EA for $\mathrm{C}_{10} \mathrm{H}_{13} \mathrm{O}_{2} \mathrm{~N}$ found (\%) (required): $\mathrm{C} 66.9$ (67.0), H 7.5 (7.5), N 7.6 (7.6).

Ethyl $N$-[(2-methoxy)phenyl]oxalamate (7b). Obtained from 2-methoxymethylaniline and ethyl chlorooxoacetate as a viscous hygroscopic yellow liquid in $85 \%$ yield. ${ }^{1} \mathrm{H}$ NMR $(\delta): 9.40$ $\left(\mathrm{t}, 1 \mathrm{H},{ }^{3} \mathrm{~J}=5.9, \mathrm{NH}\right), 7.43\left(\mathrm{t}, 1 \mathrm{H},{ }^{3} \mathrm{~J}=7.8, \mathrm{H} 4\right), 7.33\left(\mathrm{~d}, 1 \mathrm{H},{ }^{3} \mathrm{~J}=7.3, \mathrm{H} 6\right), 7.16\left(\mathrm{~d}, 1 \mathrm{H},{ }^{3} \mathrm{~J}=8.1\right.$, 
H3), $7.09\left(\mathrm{t}, 1 \mathrm{H},{ }^{3} \mathrm{~J}=7.3, \mathrm{H} 5\right), 4.52\left(\mathrm{~d}, 2 \mathrm{H},{ }^{3} \mathrm{~J}=6.2, \mathrm{NCH}_{2}\right), 4.43\left(\mathrm{q}, 2 \mathrm{H},{ }^{3} \mathrm{~J}=7.1, \mathrm{OCH}_{2}\right), 3.99$ $\left(\mathrm{s}, 3 \mathrm{H}, \mathrm{OCH}_{3}\right), 1.46\left(\mathrm{t}, 3 \mathrm{H},{ }^{3} \mathrm{~J}=7.2, \mathrm{CH}_{3}\right) \cdot{ }^{13} \mathrm{C} \mathrm{NMR}(\delta): 161.5(\mathrm{~s}, \mathrm{OC}=\mathrm{O}), 158.1(\mathrm{~s}, \mathrm{NC}=\mathrm{O})$, 157.2 (s, C2), 128.9 (d, C4), 128.0 (d, C6), 126.3 (s, C1), 120.8 (d, C5), 111.1 (d, C3), 62.7 (t, $\left.\mathrm{OCH}_{2}\right), 55.9$ (t, $\left.\mathrm{NCH}_{2}\right), 38.3\left(\mathrm{q}, \mathrm{OCH}_{3}\right), 14.4\left(\mathrm{q}, \mathrm{CH}_{3}\right) . \mathrm{IR}\left(\mathrm{cm}^{-1}\right): 3321(\mathrm{~b}, \mathrm{NH}), 1735,1690$ (s, vs, $2 \mathrm{C}=\mathrm{O}$ ). $\mathrm{EA}$ for $\mathrm{C}_{12} \mathrm{H}_{15} \mathrm{O}_{4} \mathrm{~N} \cdot 0.2 \mathrm{H}_{2} \mathrm{O}$ found (\%) (required): $\mathrm{C} 60.0$ (59.8), H 6.7 (6.5); N 5.9 (5.8).

$N, N^{\prime}$-Bis[(2-methoxymethyl)phenyl]oxalamide (7c). Obtained from 2-methoxymethylaniline and oxalyl chloride as a white solid in $90 \%$ yield, m.p. $=185{ }^{\circ} \mathrm{C} .{ }^{1} \mathrm{H}$ NMR $(\delta): 9.22\left(\mathrm{t}, 1 \mathrm{H},{ }^{3} \mathrm{~J}=\right.$ 6.2, NH), $7.41\left(\mathrm{t}, 1 \mathrm{H},{ }^{3} \mathrm{~J}=7.8, \mathrm{H} 4\right), 7.27(\mathrm{~d}, 1 \mathrm{H}, \mathrm{J}=7.2, \mathrm{H} 6), 7.16\left(\mathrm{~d}, 1 \mathrm{H},{ }^{3} \mathrm{~J}=8.2, \mathrm{H} 3\right), 7.08(\mathrm{t}$, $\left.1 \mathrm{H},{ }^{3} \mathrm{~J}=7.4, \mathrm{H} 5\right), 4.51\left(\mathrm{~d}, 2 \mathrm{H},{ }^{3} \mathrm{~J}=6.3, \mathrm{CH}_{2}\right), 3.99\left(\mathrm{~s}, 3 \mathrm{H}, \mathrm{CH}_{3}\right) .{ }^{13} \mathrm{C} \mathrm{NMR}(\delta): 160.8(\mathrm{~s}, \mathrm{C}=\mathrm{O})$, 157.6 (s, C2), 129.0 (d, C4), 128.5 (d, C6), 126.7 (s, C1), 121.0 (d, C5), 111.7 (d, C3), 56.2 (t, $\mathrm{CH}_{2}$ ), 38.7 (q, $\mathrm{CH}_{3}$ ). IR ( $\mathrm{cm}^{-1}$ ): 3290 (vs, NH), 1654 (vs, $\mathrm{C}=\mathrm{O}$ ). EA for $\mathrm{C}_{18} \mathrm{H}_{20} \mathrm{O}_{4} \mathrm{~N}_{2}$ found (\%) (required): C 65.7 (65.8), H 6.1 (6.2), N 8.2 (8.5).

\section{General procedure for NLF and van't Hoff data treatments}

Herein and for clarity reasons a brief description of the methodology developed by Llor et al., ${ }^{21}$ is given. For a fast equilibrium between hydrogen bonded state (HB) and solvent hydrogen bonded state (SB), the average chemical shift $\delta_{\text {obs }}$ for a particular nucleus is given by

$$
\delta_{\text {obs }}=x_{T H B} \delta_{T H B}+x_{S B} \delta_{S B}
$$

Where $x_{T H B}, x_{S B}, \delta_{T H B}$ and $\delta_{S B}$ are the molar fractions, and the chemical shifts of the intramolecularly hydrogen bonded specie and the solvent bonded specie, respectively.

$$
K(T)=\frac{x_{S B}}{x_{T H B}}=\frac{\delta_{o b s}-\delta_{T H B}}{\delta_{S B}-\delta_{o b s}}
$$

Integrating the Clausius-Clapeyron equation between a reference equilibrium constant $K_{R}$ at temperature $T_{R}$, and then combining with equation 2 gives the following equation

$$
\delta_{o b s}=\frac{\delta_{T H B}+\delta_{S B} K_{R} E}{1+K_{R} E}
$$

where

$$
E=\exp \left[\frac{\Delta H^{\circ} \Delta T}{R T T_{R}}\right]
$$

and

$$
K_{R}=\frac{\delta_{R}-\delta_{T H B}}{\delta_{S B}-\delta_{o b s}} ; \Delta T=T-T_{R} \text { and } \Delta H^{\circ} \text { is the enthalpy of the process }
$$

Equation 3 predicts a non-symmetrical sigmoid curve with a high temperature asymptote equal to $\delta_{S B}$ and low temperature asymptote equal to $\delta_{T H B}$. A non-linear fitting procedure is used to obtain the values of the four variables $\delta_{T H B}, \delta_{S B}, K_{R}$ and $\Delta H^{\circ}$. This equation is restricted to three variables fixing the value obtained for $\delta_{T H B}$ (vide infra) and then recalculating the others. Finally the van't Hoff plot was used to calculate $\Delta H^{\circ}$ and $\Delta S^{\circ}$ from a linear fitting procedure.

$$
\ln K=\frac{\Delta S^{\circ}}{R}-\frac{\Delta H^{\circ}}{R} \frac{1}{T}
$$


To start with, a set of values for $\delta_{T H B}=\delta_{o b s 303}+0.5, \delta_{S B}=\delta_{o b s 393}-0.5, K_{R}=0.1$ and $\Delta H^{\circ}=$ $1600 \mathrm{~kJ} \mathrm{~mol}^{-1}$ were used as initial values. Usually, $\delta_{T H B}$ was determined with the smallest associated error, this value was fixed and the other three variables were again calculated using the previously calculated values as the initial ones. The NLFP were converged at 0.9994 of fitting coefficient or higher and maximum chi squared of $45 \times 10^{-5}$ or smaller.

\section{Acknowledgements}

Financial support from Secretaría de Posgrado de Investigación del Instituto Politécnico Nacional is gratefully acknowledged. Thanks to Dr. A. R. Tapia-Benavides from UAEH for the access to EA facilities.

\section{References and Notes}

1. Martínez-Martínez, F. J.; Ariza-Castolo, A.; Tlahuext, H.; Tlahuextl, M., Contreras, R. $J$. Chem. Soc., Perkin Trans. 2 1993, 1481.

2. Jeffrey, G. A.; Saenger, W.; Hydrogen Bonding in Biological Structures; Springer-Verlag: Berlin, Heildelberg, 1991.

3. Rozas, I.; Alkorta, I.; Elguero, J., J. Phys. Chem. A 1998, 102, 9925.

4. Taylor, R.; Kennard, O.; Versichel, W. J. Am. Chem. Soc. 1984, 106, 244.

5. Jeffrey, G. A.; Mitra, J.; J. Am. Chem. Soc. 1984, 106, 5546.

6. Preißner, R.; Enger, U.; Saenger, W.; FEBS Letters 1991, 288, 192.

7. Nelson, H. C. M.; Finch, J. T.; Luisi, B. F.; Klug, A. Nature 1987, 330, 221.

8. Goodsell, D. S.; Kopka, M. L.; Dickerson, R. E. Biochemistry 1995, 34, 4983.

9. Zhu, J.: Parra, R. D.; Zeng, H.; Skrzypezak-Jankun, W.; Zeng, X.; Gong, B. J. Am. Chem. Soc. 2000, 122, 4219.

10. Hamuro, Y.; Geib, S. J.; Hamilton, A. D. Angew. Chem. Int. Ed. 1994, 33, 446; Ibid., J. Am. Chem. Soc. 1996, 118, 7529.

11. Pham, M.; Gdaniec, M.; Połonski, T. J. Org. Chem. 1998, 63, 3731.

12. Parra, R. D.; Zeng, H.; Zhu, J.; Zheng, C.; Zeng, X. C.; Gong, B. Chem. Eur. J. 2001, 7, 4352 .

13. Desseyn, H. O.; Perlepes, S. P.; Clou, K.; Blaton, N., Venken, B. J.; Dommisse, R.; Hansen, P. E. J. Phys. Chem. A. 2004, 108, 5175.

14. Yang, J.; Gellman, S. H. J. Am. Chem. Soc. 1998, 120, 9090.

15. Sośnicki, J. G.; Hansen, P. E. J. Mol. Struct. 2004, 700, 91.

16. (a) Gellman, S. H.; Adams, B. R.; Dado, G. P. J. Am. Chem. Soc. 1990, 112, 460. (b) Gellman, S. H.; Dado, G. P.; Liang, G-B.; Adams, B. R. J. Am. Chem. Soc. 1991, 113, 1164. (c) Liang, G-B., Desper, J. M.; Gellman, S. H. J. Am. Chem. Soc. 1993, 115, 925. (d) Dado, 
G. P.; Gellman, S. H. J. Am. Chem. Soc. 1994, 116, 1054. (e) Gung, B. W.; Zhu, Z.; Zou, D.; Everingham, B.; Oyeamalu, A.; Crist, R. M.; Baudlier, J. J. Org. Chem. 1998, 63, 5750.

17. Kessler, H. Angew. Chem. Int. Ed. 1982, 21, 512.

18. Martínez-Martínez, F. J.; Padilla-Martínez, I. I.; Brito, M. A.; Geniz, E. D.; Rojas, R. C.; Saavedra, J. B.; Höpfl, H., Tlahuextl, M., Contreras, R. J. Chem. Soc., Perkin Trans. 2, 1998, 401.

19. Padilla-Martínez, I. I.; Martínez-Martínez, F. J.; García-Báez, E. V.; Torres-Valencia, J. M.; Rojas-lima, S.; Höpfl, H. J. Chem. Soc., Perkin Trans. 2001, 2, 401.

20. Padilla-Martínez, I. I.; Martínez-Martínez, F. J.; Guillén-Hernández, C. I.; Chaparro-Huerta, M.; Cabrera-Pérez, L. C.; Gómez-Castro, C. Z.; López-Romero, B. A.; García-Báez, E. V. ARKIVOC 2005, 401.

21. Llor, J.; Lopez-Mayorga, O.; Muñoz, L. Magn. Res. Chem. 1993, 31, 552-556; Llor, J.; Muñoz, L. J. Org. Chem. 2000, 65, 2716.

22. Gutowsky, H. S.; Saika, A. J. Chem. Phys. 1953, 21, 1688.

23. Schullery, S. E.; Scott, R. M. J. Mol. Struct. 1994, 322, 287.

24. Hoffman, M.; Rychlewska, U.; Warżajtis B. CrystEngComm. 2005, 7, 260.

25. Shabani, M.; Monajjemi, M.; Aghai, H. J. Chem. Research (S) 2003, 249.

26. Alemán, C.; Puiggal, J. J. Org. Chem. 1999, 64, 351.

27. Hibbert, F.; Mills, J. F.; Nyburg, S. C.; Parkins, A. W. J. Chem. Soc., Perkin Trans. 2 1998, 629.

28. Gómez, M.; Gómez-Castro, C. Z.; Padilla-Martínez, I. I.; Martínez-Martínez, F. J.; González, F. J. J. Electroanal. Chem. 2004, 567, 269.

29. García-Báez, E. V.; Gómez-Castro, C. Z.; Höpfl, H.; Martínez-Martínez, F. J.; PadillaMartínez, I. I. Acta Cryst. 2003, C59, o541.

30. Naik, S.; Bhattacharjya, G.; Talukdar, B.; Patel, B. K. Eur. J. Org. Chem. 2004, 6, 1254.

31. Yavari, I.; Nasiri, F.; Djahaniani, H.; Bijanzadeh, H. R. J. Chem. Res. 2005, 8, 537.

32. Slater, H. L.; Rozynski, H.; Crundwell, G.; Glagovich, N. M. Acta Cryst. 2006, E62, o1957. 